\title{
Puma (Puma concolor), a top predator in Sierra del Tentzo Nature Reserve in Central Mexico
}

\author{
O. Eric Ramírez-Bravo ${ }^{1 *}$, Alexandro Fernández Aguilar ${ }^{2}$ and Daniel Jiménez-García ${ }^{3}$ \\ 'Departamento Universitario para el Desarrollo Sustentable, Instituto de Ciencias, Benemérita Universidad Autónoma de Puebla. \\ 14 Sur 6301-CU, CP. 72570, Puebla. Puebla, México. E-mail: osvaldoeric.ramirez@correo.buap.mx (OERB) \\ ${ }^{2}$ Motocle A.C., Av. Maximino Ávila Camacho 1019-9, San Andrés Cholula, CP. 72810, Puebla. Puebla, México. E-mail: alx 1621@ \\ hotmail.com (AFA) \\ ${ }^{3}$ Centro de Agroecología Instituto de Ciencias, Benemérita Universidad Autónoma de Puebla. 14 Sur 6301-CU, CP. 72570, Puebla. \\ Puebla, México. E-mail: jimenez.daniel@correo.buap.mx (DJG) \\ *Corresponding author
}

\begin{abstract}
The puma (Puma concolor) is the felid with the broadest distribution in America and plays a key role in the environment. However, there is scarce information about the species, as well as on how habitat loss, prey depletion and hunting have affected puma population along its range. Thus, it is imperative to generate information on the presence and distribution of puma in highly fragmented habitats like Central Mexico. We conducted a camera trapping survey to determine deer densities during September 2012 along trails in remnants of oak forest near the town of San Nicolas Huajuapan in the municipality of Huehuetlan el Grande, Puebla (18 $46^{\prime} 57.18^{\prime \prime} \mathrm{N}^{\prime}-98^{\circ} 07^{\prime} 18.95^{\prime \prime}$ W). A photograph of an adult puma of undetermined sex was obtained at 00:32 hours on September 16 near a dry river bed at 1,680 masl. During the same season, we also captured other species like white tailed deer (Odocoileus virginianus), ringtail (Bassariscus astutus), coyote (Canis latrans) and grey fox (Urocyon cinereoargenteus). This record is important as the closest protected area presumably inhabited by puma is the lzta-Popo Nature Reserve; other sightings have also been recorded in the Mixteca Poblana and the Tehuacán-Cuicatlán Biosphere Reserve. This record is noteworthy because the species distribution in the state is unknown. A distance analysis showed that this site is relevant for connecting different puma populations in Central Mexico.
\end{abstract}

El puma (Puma concolor) es el felino con la mayor distribución en el continente Americano y juega un papel importante en su medio ambiente. Sin embargo, la información sobre la especie es escasa y como la pérdida de hábitat, la disminución de presas y la caza de individuos han afectado a las poblaciones a lo largo de su distribución. Por lo que, es importante generar información sobre su presencia y distribución en hábitats altamente fragmentados como el centro de México. Se condujo un muestreo usando cámaras trampa para determinar la densidad de venados durante el mes de septiembre de 2012, colocándolas a una altura de entre 40 y $50 \mathrm{~cm}$, a lo largo de veradas localizadas en remanentes de bosque de encino cerca de la comunidad de San Nicolás Huajuapan, Municipio Huehuetlan el Grande, Puebla (18 ${ }^{\circ} 46^{\prime} 57.18^{\prime \prime} \mathrm{N}-98^{\circ} 07^{\prime}$ $18.95^{\prime \prime}$ W). Se obtuvo la fotografía de un puma adulto a las 00:32 horas del 16 de septiembre cerca de un arroyo seco a una elevación de 1,680 msnm. En la mismo periodo de muestreo, se fotografiaron otras especies como el venado cola blanca (Odocoileus virginianus), el cacomixtle (Bassariscus astutus), el coyote (Canises latrans) y la zorra gris (Urocyon cinereoargenteus). El registro de puma en la Sierra del Tentzo es importante, debido a que se encuentra muy próxima e intermedia entre otras regiones en las que se tiene información sobre la presencia de pumas, tales como: el Parque Nacional Izta-Popo, la Mixteca Poblana y en la Reserva de la Biósfera de Tehuacán-Cuicatlán. Este registro es importante ya que se desconoce la distribución de la especie dentro del estado. Un análisis de distancia muestra que, la reserva es un sitio importante para conectar diferentes poblaciones de puma en el Centro de México.

Keywords: Carnivore; corridor; natural protected área; Tentzo, Puebla

C 2018 Asociación Mexicana de Mastozoología, www.mastozoologiamexicana.org

\section{Introduction}

The puma (Puma concolor) is the felid with the broadest distribution in America, ranging from Canada to southern Argentina and Chile, where it inhabits almost all available habitats (Nowak 2005). This species plays a key role in the environment in arid and temperate areas where it a top predator; hence, its absence has a profound effect on ecological interactions (Allen et al. 2014). However, there is scarce information about the species, as well as on how habitat loss, prey depletion and hunting have affected puma populations along its range (Hernandez-Saintmartín et al. 2013). Furthermore, natural habitats have been reduced across its range, forcing the species to adapt to fragmented landscapes (Hernandez-Saintmartín et al. 2013); thus, small protected areas play a key role in the conservation of big felid species (Núñez 2010).

This is the case in Central Mexico, where protected areas are surrounded by a matrix of extensive agricultural land and urban areas. One such reserves is Sierra del Tentzo in Puebla, an area that was decreed as a state reserve in 2011 (Figure 1). It has a rugged terrain with elevations ranging from 2,000 to 2,350 masl; it has a mild dry climate with monthly mean temperatures between $16^{\circ} \mathrm{C}$ and $21.5^{\circ} \mathrm{C}$ (Instituto Nacional de Estadística, Geografía e Informática 2000; Morón et al. 2000). Sierra del Tentzo contains some of the last remnants of oak forest in the area and serves as a potential corridor between different protected areas (Periódico Oficial del Estado de Puebla 2011). Various large 
mammals thrive in the area, such as the white tailed deer (Odocoileus virginianus), collared peccary (Tayassu tajacu), and coyote (Canis latrans); however, despite of the presence of these potential prey, there had been no reports of large felids. In this note, we report the first record of puma (Puma concolor) captured during a camera-trap survey in the protected area of Sierra del Tentzo.

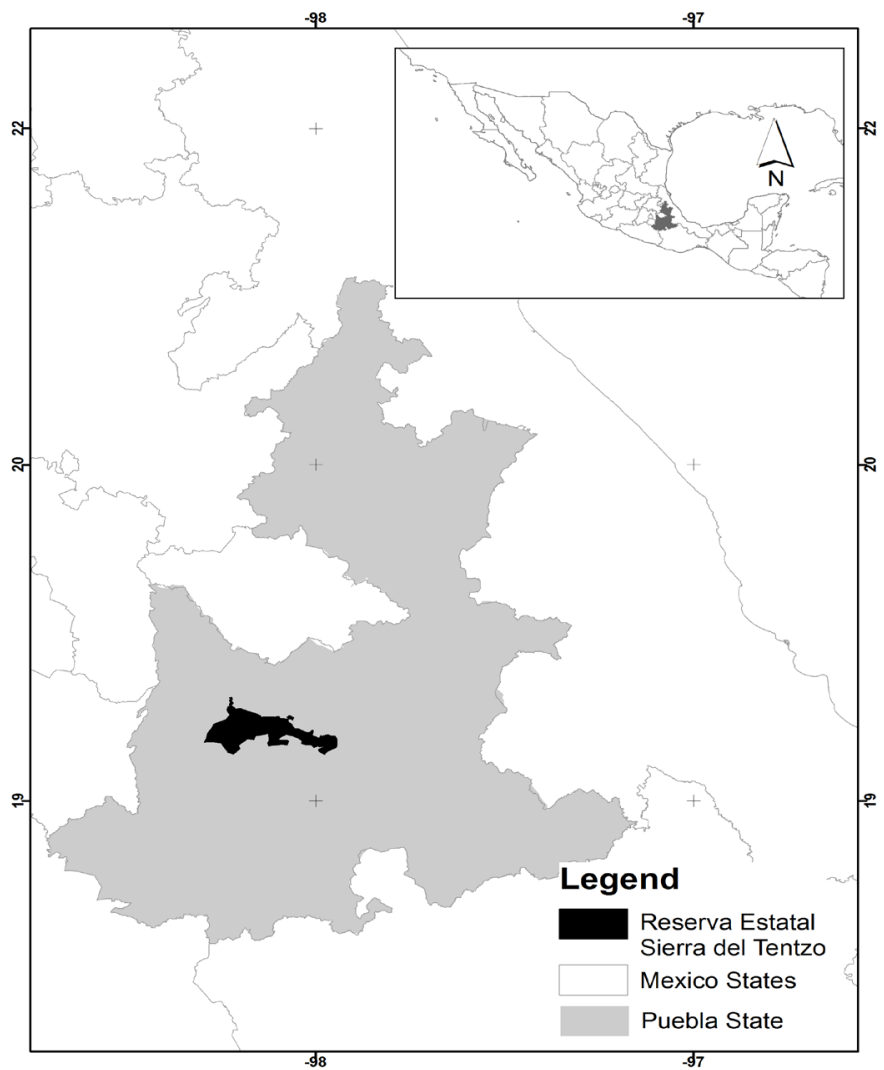

Figure 1. Location of the Sierra del Tentzo Natural Protected Area in the State of Puebla, central Mexico, where a puma specimen was recorded.

\section{Methods}

We conducted a camera-trapping survey to determine deer densities in the Sierra del Tentzo Nature Reserve. Two camera traps (Bushnell Trophy; Kansas, United States) were set for a total of 20 camera days during September 2012 spaced $1 \mathrm{~km}$ apart from each other, and at a height of 40 to $50 \mathrm{~cm}$. along trails in remnants of an oak forest near the town of San Nicolas Huajuapan in the municipality of Huehuetlan el Grande ( $\left.18^{\circ} 46^{\prime} 57.18^{\prime \prime} \mathrm{N},-98^{\circ} 07^{\prime} 18.95^{\prime \prime} \mathrm{W}\right)$. To determine the importance of the new record at the regional level in terms of connectivity, we performed an Euclidian distance analysis using the available records in GBIF for the region (Puebla, Oaxaca, Veracruz, Estado de México and Hidalgo) and the extension available in ArcMap 10.1.

\section{Results}

A photograph of an adult puma was captured at 00:32 hours on September 16 near a dry river bed at an elevation of 1,680 $\mathrm{m}$ (Figure 2). In the same camera trap, we captured other species like ringtail (Bassariscus astutus), and grey fox (Urocyon cinereoargenteus); other cameras also recorded white tailed deer (Odocoileus virginianus) and coyote (Canis latrans). Dis-

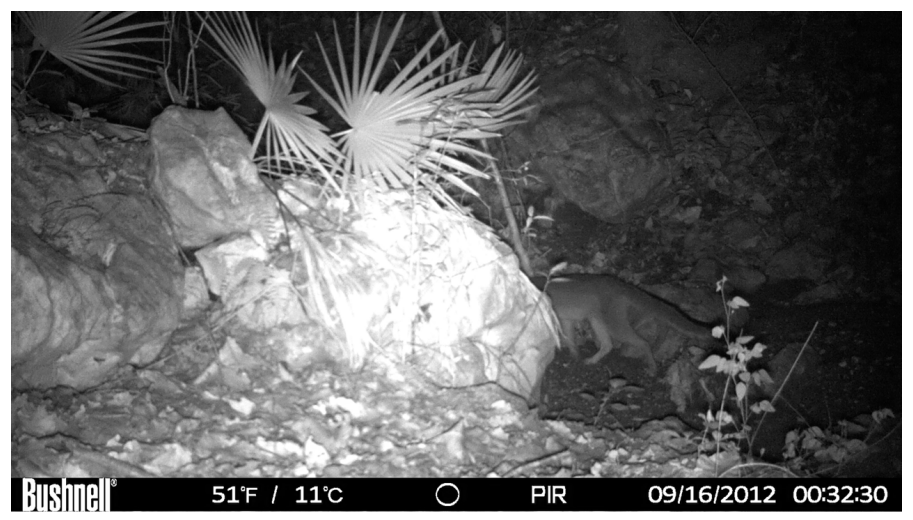

Figure 2. Photograph of a wild Puma (Puma concolor) in the Sierra del Tentzo Protected Area.

tances to other capture sites were consistently reduced, from $34 \mathrm{~km}$ to $8 \mathrm{~km}$, according to Euclidian distances.

\section{Discussion and Conclusions}

This record is noteworthy, as puma populations are expected to be distributed in a metapopulation structure in fragmented areas such as central Mexico (Miotto et al. 2012), and those limited by distance or habitat barriers would experience a limited gene flow (McRaer et al. 2005). We considered the existence of a metapopulation in the region, as the analysis showed that the distance between records previously obtained in Puebla (Figure 2; RamírezBravo and Hernández-Santín 2016; Ramírez-Pulido et al. 2005; Velázquez et al. 2001) and in other states (Fuller et al. 2006; Soria-Díaz et al. 2010) is lower than the dispersal distances previously recorded for the species (Elbroch et al. 2009; Sweanor et al. 2000); however, further information is needed. The protected area closest to our study site inhabited by pumas is the Izta-Popo Nature Reserve, located 58 $\mathrm{km}$ away. Further sightings of the species were obtained between years 2008 and 2013 in the Mixteca Poblana in the southwest, and in the Tehuacán-Cuicatlán Biosphere reserve in the southeast, located at $73 \mathrm{~km}$ and $93 \mathrm{~km}$ from the study area, respectively (Ramírez-Bravo and Hernández-Santín 2016). Thus, our record suggests that Sierra del Tentzo could provide a suitable corridor for the dispersal of the species, as it is home to potential prey like white-nosed coati (Nasua narica), and white tailed deer (Odocoileus virginianus); additionally, this area has a low human density, and our puma record was captured $3 \mathrm{~km}$ away from the closest town (448 inhabitants). As a final recommendation, and as suggested for other fragmented areas with a urbanized matrix which hampers migration, it is imperative to maintain remnant forest fragments such as Sierra del Tentzo, which likely facilitate the dispersal of wild species (Miotto et al. 2012).

\section{Literature cited}

Allen, M. L., L. M. Elbroch, D. S. CAsady, And H. U. Wittmer. 2014. Seasonal variation in the feeding ecology of Pumas (Puma concolor) in Northern California. Canadian Journal of Zoology 92:397-403. 
Elbroch, M., H. U. Wittmer, C. Saucedo, and P. Corti. 2009. Longdistance dispersal of a male puma (Puma concolor puma) in Patagonia. Revista Chilena de Historia Natural 82:459-461

Fuller, T., M. Munguía, M. Mayfield, V. Sánchez-Cordero, and S. SARKAR. 2006. Incorporating connectivity into conservation planning: A multicrieria case from Central Mexico. Biological Conservation 133:131-142.

Hernández-Saintmartín, A. D., O. C. Rosas-Rosas, J. Palacio-Nuñez, L. A. Tarango-Arámbula, F. Clemente-Sánchez, and A. L. Hoogesteinn. 2013. Activity patterns of jaguars, puma and their potential prey in San Luis Potosi, Mexico. Acta Zoológica Mexicana (n. s.) 29:520-533

Instituto Nacional de Estadística, Geografía e Informática (INEGI). 2000. Síntesis Geográfica del estado de Puebla. Instituto Nacional de Estadística Geografía e Informática. Mexico.

McRae, B. H., P. Beier, L. E. Dewald, L.Y. Huynh, and P. Keim. 2005. Habitat barriers limit gene flow and illuminate historical events in a wide-ranging carnivore, the American puma. Molecular Ecology 14:1965-1977.

Miotto R. A., M. Cervini, R. A. Begotti, and P. M. Galetti, JR. 2012. Monitoring a Puma (Puma concolor) Population in a Fragmented Landscape in Southeast Brazil. Biotropica 44:98-104.

Morón, M. A, A. Aragón, A. M. Tapia-Rojas, and R. Rojas-García. 2000. Coleoptera lamellicornia de la Sierra del Tentzo, Puebla, México. Acta zoológica mexicana 79:77-102.

Nowak, R. M. 2005. Walker's Carnivores of the World, The Johns Hopkins University Press, U.S.A.

NúÑEZ, R. 2010. Estimating jaguar population density using camera-traps: a comparison with radio-telemetry estimates. Journal of Zoology 129: 487-496.

Periódico Oficial del Estado de Puebla. 2011. Declaratoria del Área Natural Protegida de la Sierra del Tentzo. 12:1-12.

Ramírez-Bravo, O. E., and L. Hernández-Santín. 2016. Carnivores (Mammalia) from areas of Nearctic-Neotropical transition in Puebla, central Mexico: presence, distribution, and conservation. Check List 12:1-17.

Ramírez-Pulido, J., N. González-Ruiz, and H. H. Genoways. 2005. Carnivores from the Mexican state of Puebla: distribution, taxonomy and conservation. Mastozoología Neotropical 12:37-52.

Soria-Díaz, L., O. Monroy-Vilchis, C. Rodríguez-Soto, M. M. ZARCO-GonzÁleZ, AND V. URIOS. 2010. Variation of abundance and density of Puma concolor in zones of high and low concentration of camera traps in Central Mexico. Animal biology 60:361-371.

Sweanor, L. L., K. A. Logan, and M. G. Hornocker. 2000. Cougar dispersal patterns, metapopulation dynamics, and conservation. Conservation Biology 14:798-808.

Velázquez, A., F. J. Romero, H. Rangel-Cordero, and W. H. Gerrit. 2001. Effects of landscape changes on mammalian assemblages at Izta-Popo Volcanoes, Mexico. Biodiversity and Conservation 10:1059-1075.

Associated editor: Jorge Servin

Submitted: June 15, 2017; Reviewed: August 14, 2017;

Accepted: November 12, 2017; Published on line:December 18, 2017. 
PUMA TENTZO, PUEBLA, MÉXICO

98 THERYA Vol. 9(1): 95-97 